\title{
Impact of JDI and Personality Traits on Job Satisfaction
}

\author{
Zeeshan Arshad \\ Department Of Management Sciences, Foundation University Rawalpindi Campus
}

\begin{abstract}
The study concludes that both personality traits and JDI are ingredients of job satisfaction. These have implication for human resource manager in performing his/her tradition Human resource functions. We believe that personality traits must be considered in recruitment and selection procedures. Getting right person for the right job can be ensured by taking in to account the person's personality. Further for retention we propose that JDI can give help to human resource manager in retaining work force. By making job challenging and exciting, ensuring justice in pay and promotion and by establishing mentoring programs, we believe that an employee will be retained in organization.

Key Words: Job Description Index, Personality Traits, Job Satisfaction.
\end{abstract}

\section{Introduction}

The significance of job satisfaction is a proven fact in many of the fields e.g organizational behavior, sociology, strategic management $\&$ human resource management etc. The reason is that where job exists the need for job satisfaction also exists. In the earlier of $20^{\text {th }}$ century, with initial work in scientific management by Taylor and Elton Mayo, the focus was given upon the ways that enhance job satisfaction of employees. Similarly, later work by Maslow and other researchers have also contributed to the literature of job satisfaction. With the development of job satisfaction literature, different theories have been developed from time to time. Worrell (2004) have presented three conceptual frameworks of different job satisfaction theories which are content theory, process theory and situational theory frameworks. The first explains that job satisfaction exists when growth and self actualization needs are fulfilled. The second framework explains that job satisfaction occurs upon fulfillment of one's expectations and values and the third framework that refers to the situational theory suggests that job satisfaction comes when individual's personal characteristics fit together with organizational characteristics.

There has been extensive amount of literature available on job satisfaction but the need yet exists to make comparison of different antecedents of job satisfaction to know which one effect more to predict job satisfaction. Thus, big five personality traits (Neuroticism, Extraversion, Openness to experience, Agreeableness and Conscientiousness) and Job description index (work itself, pay, supervision, coworkers and promotional opportunities) are taken as antecedents/independent variables to compare their impact on job satisfaction. The both antecedents are actually backed by situational and dispositional theories of job satisfaction.

Thus the purpose of present study is to make comparison of big five personality traits and JDI with job satisfaction in order to find that which one has more importance to predict job satisfaction of employees.

\section{Problem Statement}

Keeping the above discussion in view, the researcher plans to study the comparison of Job description index and personality traits and their impact on job satisfaction.

\section{Purpose of Study}

The purpose of study is to make comparison of job description index and big five personality traits with job satisfaction in order to find that which one has more importance to predict job satisfaction of employees.

\section{Literature Review}

Since the origin of scientific management, construct of job satisfaction has widely been studied by the researchers. In 1911, job satisfaction was studied by Taylor when he started to learn about employees and their job duties in order to develop more sophisticated ways to train them (Taylor, 1911). Afterwards in 1927, Elton Mayo conducted the study about the effects of lighting on the productivity of workers wherein employees' positive and negative reactions toward jobs were studied (Bruce \& Walton; 1992). In 1932, he has added additional factors like temperature, breaks, fatigue, and working hours that impact on the productivity of workers which result in positive or negative reactions from the workers. In 1970, Maslow presented hierarchy of need theory (A motivation theory) which is deemed as a great contribution in the job satisfaction literature. The theory explains that there are five specific needs in the life which are physiological needs, safety needs, 
social needs, self-esteem needs, and self-actualization needs. When the needs of the workers are fulfilled they are deemed to be satisfied at work.

The conception of job satisfaction is supported by number of theories developed in different point of time. However, three conceptual frameworks of these theories are established which deemed as more prominent in the literature (Worrell, 2004). These frameworks include content theory, process theory and situational theory. The content theory framework explains that workers will be satisfied with their jobs when their growth and self actualization needs are fulfilled. The process theory framework is that job satisfaction occurs after fulfillment of one's expectations and values. The third framework is referred as situational theory where job satisfaction comes when individual's personal characteristics fit together with organizational characteristics (Worrell, 2004). Furthermore, a famous theory of job satisfaction i.e dispositional theory must not be ignored. Many research scholars have highlighted the role of dispositional factors in job satisfaction of employees. Various academicians argue that extensive amount of literature reviewed during 1980-1995 has general support that job satisfaction is based upon dispositional factors (House, Shane \& Herold, 1996).

At this stage, it is a proven fact that there has been an extensive amount of literature available about job satisfaction. However, need yet exists to carry out such studies to compare which theory of job satisfaction worth more to satisfy the employees at their jobs. Based on same, present study is proposed to compare situational \& content theories of job satisfaction with dispositional theory of job satisfaction.

The factors extracted from the situational theory are situational characteristics e.g pay, supervision, coworkers \& promotional activities etc. On other hand, work itself is the product of content theory (Hackman \& Oldham, Herzberg \& Maslow's work). These factors are merged in the Job Description Index (JDI) which includes work itself, pay, promotion, supervision and coworkers (Smith, Kendall, \& Hulin, 1969). Similarly, factors extracted from the dispositional theory include big five personality traits which are Neuroticism, Extraversion, Openness to experience, Agreeableness and Conscientiousness (Digman, 1990).

In a more simple way, the present study is to examine the impact of big five personality traits and Job description index (JDI) on job satisfaction of employees. The purpose of the study is to compare that which variable has greater or lesser impact on job satisfaction in comparison to other. Therefore, the relationship between big five personality traits and job description index with job satisfaction is discussed individually as follow;

\section{Personality traits -Job Satisfaction Relationship}

Personality traits are the stable modes of individuals which remain fixed across their life cycles (Costa $\&$ McCrae, 1997). This notion has support through number of empirical studies (Nyhus and Pons, 2005; Mueller and Plug, 2006). According to the definition of Cattell (1965);

\section{"Personality is the cognitive and behavioral patterns which are stable over time and across situations".}

The importance of personality traits is high as these traits greatly impact on the individuals' values and attitudes (Olver and Mooradian, 2003). Because of their importance, a consensus in the field of social psychology has been merged on behalf of well known taxonomy of five personality traits (Goldberg, 1993; McCrae \& John, 1992). It is mostly known as five factor model (FFM) or 'The Big Five'. The big five personality traits or factors are neuroticism, extraversion, openness to experience, agreeableness and conscientiousness (Digman, 1990).

The five factor model of personality is a comprehensive classification of personality traits which has strong empirical support (Digman, 1990; Goldberg, 1993; Costa \& McCrae, 1997). The proponents of the big five argue that this taxonomy is useful for academicians because it is comprehensive, systematic, well structured and helpful for understanding human behaviors (McAdams, 1992).

Thus based on literature support, it is argued that five factor model of personality plays significant role in understanding human values, attitudes and behaviors. (McAdams, 1992; Olver at al, 2003). There have been extensive amount of literature available where relationship between personality and different human attitudes and behaviors have been established. In this regard, studies with respect to the relationship between personality traits and job outcomes (e.g Job satisfaction, job commitment, job performance \& intentions to leave etc) are of worth mentioning (Furnam \& Zacherl, 1986; Barrick \& Mount, 1991, Cannoly \& Viswesvarans, 2000; Judge et $\mathrm{al}, 2002)$.

A famous theory of job satisfaction is the Dispositional theory which identifies that people have certain types of innate dispositions that affect them towards their job satisfaction. Moreover, it is argued by the researchers that extensive amount of literature reviewed during 1980-1995 has general support that job satisfaction is based upon dispositional factors (House, Shane \& Herold, 1996).

Thus based on the importance of personality traits in the literature of job outcomes, each personality trait with job satisfaction is hypothesized here. Job satisfaction which is defined as "An employee's attitude towards one's job particularly positive feeling about one's job” (Cranny, Smith \& Stone, 1992). 


\subsection{Extraversion and Job Satisfaction Relationship:}

Individuals who possess such type of personality traits are more friendly, sociable, gregarious, talkative and active (Goldberg, 1990; Digman, 1990). These people have the abilities to make social networks and therefore easily get important information pertaining to their short term/long term benefits in the organization (Raja, John and Ntalianis, 2004). Such information enables them in their career decision making and to choose the right path for their career growth. Moreover, because extraverts are more sociable therefore they find social interactions more positive and beneficial than their colleagues (Watson \& Clark, 1997). Therefore, at the time of getting rewards such people are more satisfied with their jobs.

In a number of studies, a positive relationship between extraversion and job satisfaction of employees has been found (House, Shane, \& Herold, 1996; Watson \& Clark, 1997). A Meta analysis study of big five and job satisfaction was recently carried out which found strong correlations of extraversion with job satisfaction (Judge at al, 2002).

\subsection{Openness to Experience and Job Satisfaction Relationship:}

Those individuals who are high on openness to experience signifies traits as curious, broad-minded, cultured and intelligent (Goldberg, 1990).

The relationship between openness to experience and job satisfaction is based upon self verification theory. The theory premises that people generally develop a perception about themselves and once they form self-views they stabilize these views by seeking and embracing experiences that match their self views and by avoiding or rejecting experiences that challenge them (Swann, 1983).

Similarly, the theory applies in the relationship between openness to experience and job satisfaction. Since favorable rewards pay or promotions, fair treatment will be more self enhancing and self verifying for the individuals who are high on openness to experience; they are likely to react more favorably than those who are low in openness to experience.

\subsection{Neuroticism and Job Satisfaction Relationship:}

The common traits of high neuroticism include being nervous, depressed, anxious, embarrassed, fearful, worried and insecure (Barrick \& Mount, 1991). On other hand, the common traits of low neuroticism are being tough, worriless, calm, ruthless, confident and stable. In a recent Meta analysis study, neuroticism is proved as one of the strongest and most consistent correlate of job satisfaction (Judge et al, 2001).

Neurotic individuals experience more negative life events than other individuals because their predisposition cause them to get into situations that foster negative affect (Emmons, Diener \& Larsen, 1985). When such situations occur with respect to the jobs, they lead towards diminished level of job satisfaction. However, individuals low in neuroticism is likely to experience positive events show greater job satisfaction.

\subsection{Conscientiousness and Job Satisfaction Relationship:}

Individuals high in conscientiousness are painstaking, dependable, careful, thorough, organized and planful (Goldberg, 1990). In the Meta analysis study of Judge et al (2002), conscientiousness is the second largest predictor of job satisfaction after extraversion. Some other studies have also found conscientiousness as a strong predictor of job satisfaction (Barrick and Mount, 1991; Furnham, Eracleous \& Premuzic, 2011).

The individuals who are high in conscientiousness are planful, organized and careful therefore can easily become experts in their works. Therefore have more chances to be successful in their jobs that leads toward satisfaction with their jobs. On other hand, individuals low in conscientiousness are not well organized and careful in doing their jobs which means that they would have less command on their works and less chances to become successful in organization that would lead towards low level of job satisfaction.

\section{5 . Agreeableness and Job Satisfaction Relationship:}

This trait is generally interpreted as Agreeableness or likeability (Conley, 1985; Goldberg, 1987; John, 1989). Some other researchers have labeled it as Friendliness (Guilford \& Zimmerman, 1949), Social conformity or Love (Fiske, 1949; Digman \& Chock, 1981). Individuals who are high on agreeableness are highly sociable, empathetic to others and highly cooperative. However those who are low in this trait are temperamental, argumentative and emotional (Goldberg 1990).

The research shows that agreeableness trait has strong positive relationship with positive affectivity and life satisfaction (McCrae and Costa, 1991). It is also about having pleasant and satisfying type of relationships with others (Organ and Lingl; 1995). There have been a lot of studies conducted which supports that high agreeableness people are more satisfied with their jobs than disagreeable peoples.

Thus based on literature support regarding the relationship of big five personality traits and job satisfaction, following hypothesis is developed; 


\section{H1: Big five personality traits have impact on job satisfaction.}

\section{Job Description Index (JDI) - Job Satisfaction Relationship:}

Job description index (JDI) is a well known measure of job satisfaction which has been widely used by researchers as well as practitioners because of its simplicity and validity in different areas. Golembiewski and Yeager (1978) argue that job description index is deemed as the most carefully constructed measure because of the three reasons. The first is that it has been extensively applied in business and government sectors. The second reason is its construct validity and the third and final reason is that dimensional structure of JDI is generalized in different occupational groupings.

There are five dimensions of JDI given by Smith et al (1969) that include work itself, pay, supervision, coworkers and promotional opportunities available within the organization to employees. Work itself can be better explained through job characteristics model (JCM) given by Hackman \& Oldham. According to JCM, there are five core job characteristics which are skill variety, task identity, task significance, autonomy, and feedback which explain the work itself. The second dimension of JDI i.e promotional opportunities or the future prospects defined by Taormina (1997) as "the extent to which an employee anticipates having a rewarding career within his or her employing organization". The rewarding career could be in form of intrinsic or extrinsic motivation based on its worth for an individual employee. The objective of the third dimension i.e coworker support is to reduce anxiety, fear or doubt of employees (Taormina, 1997). In this regard, an empirical cross sectional study, recently conducted in Japan reveals the importance of coworker support to enhance job satisfaction and job performance of employees (Nagami et al, 2010). In their study, they have found that coworker support in year 2008 and employees' job satisfaction/performance in year 2009 is positively related and suggested that it is quite sensible to provide equally supportive environment to ensure better job performance of employees. The fourth dimension of JDI is supervision which is the relationships/networks that employee has with his supervisor/boss. The social relationships with his/her supervisor can be helpful to reduce anxiety and stress that would ultimately lead towards job satisfaction. The fifth dimension that is pay is the physical financial rewards that also play important role in the job satisfaction of employees as supported by different scholars in different point of time.

Thus based on literature support, JDI has relationship with job satisfaction of employees. Therefore, following hypothesis is developed;

H2: Job Description Index (JDI) is positively related with job satisfaction of employees. Theoretical Framework

Based on literature review, we present the following theoretical framework;

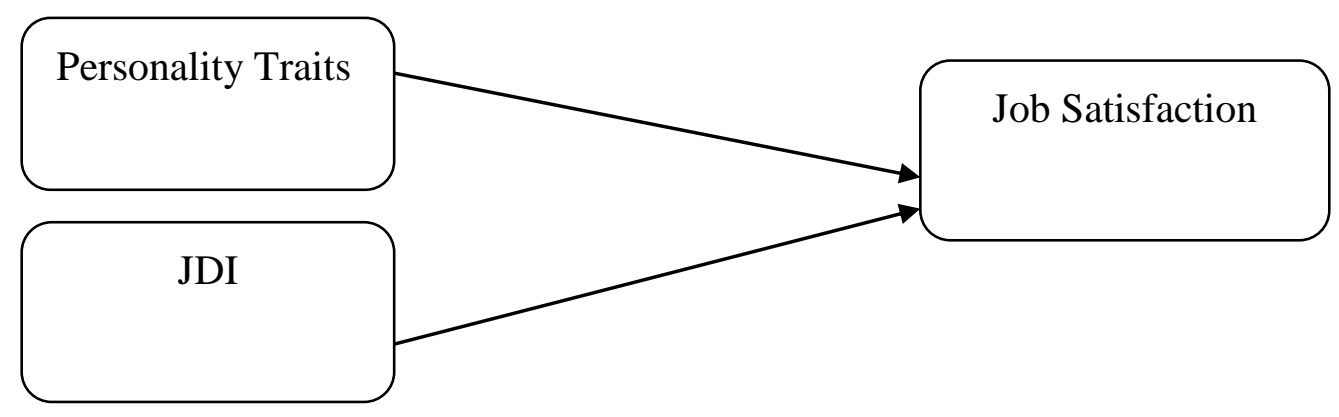

Variables:

The theoretical framework explains Job Satisfaction in terms of Individual's personality and JDI.

Sample:

A convenient sample was obtained from 100 employees working in public and private organizations in Islamabad and Rawalpindi. Convenient sample was used due to lack of finances and time. the demographics are displayed in table 1.1

Table 1.1: Descriptive Statistics

\begin{tabular}{llll} 
Demographics & & Frequency & \% ages \\
\hline Age & Between $24-30$ & 54 & $54 \%$ \\
\hline & $31-45$ & 28 & $28 \%$ \\
\hline Gender & $45 \&$ and above & 18 & $18 \%$ \\
\hline & Males & $\mathbf{8 1}$ & $\mathbf{8 1 \%}$ \\
\hline Job & Females & $\mathbf{1 9}$ & $\mathbf{1 9 \%}$ \\
\hline & Private & $\mathbf{4 9}$ & $49 \%$ \\
\hline
\end{tabular}


The sample comprised of 54 respondents between ages of 24-30, 28 respondents between ages of 31-45 and 18 respondents above the age of 45 . This indicates that sample had a good mix of people at different levels of their carriers. With the first age group, most of the respondents were at their entry level while other groups represented respondents in their mid and final stages of their carriers.

The demographics also indicate that $81 \%$ of the respondents were male while $19 \%$ of respondents were females working in different private (49\%) and public (51\%) organization. This indicates that sample includes both leading employers in Pakistan i-e public and private sectors and has representation of both genders.

\section{Measures:}

The construct of personality was measured by scale developed by Digman (1990). The scale comprised of 44 items aimed at measuring five big personality traits. Each items was rated on 5 point lickert scale with values of 1 for "Strongly Disagree", 2 for "Disagree", 3 for "Neutral", 4 for "Agree" and 5 for "Highly Agree". These items were then reduced to 32 after analysis of their Crone Bach's Alpha in the pilot study. The revised scale was then administered to the participants to measure the construct of personality traits.

The construct of JDI was measured by scale developed by Smith et al (1969). All the five attributes were summarily measured in the pilot study. The results of the pilot study indicated that 2 items from "pay", 2 items from "promotion" and 2 items from "co-workers" had to be removed for lowers Crone Bach Alphas. The revised scale was then administered to the respondents who rated their choices on 5 pont lickert scale.

The construct of job satisfaction was measured by scale developed by smith et al. (1969). The construct was measured by six items. No item was removed as its Crone Bach Alpha were significant.

Summarizing the discussion, the construct of personality traits were measured by 32 items, the construct of JDI was measured by 19 items while the construct of job satisfaction was measured by 6 items. The questioner was lengthy but easy to understand. It took an average of 12 minutes for a respondent to fill a questioner. However the researchers were there to help them if they had any query. Table 1.2 presents the reliability analysis of the questioner administered to the respondents;

\begin{tabular}{lll} 
Variables & $\begin{array}{l}\text { Table 1.2: Reliability Analysis } \\
\text { Crone bach,s Alpha }\end{array}$ & No of items \\
\hline Personality & .783 & 32 \\
\hline Job Satisfaction & .794 & 6 \\
\hline JDI & .697 & 19 \\
\hline
\end{tabular}

It can be observed from the table that Cronbach's Alpha for scale measuring constructs of Personality Traits, Job Satisfaction and JDI are .783, .794 and .697 respectively. Thus it can be inferred that reliability statistics is satisfactory.

\section{Hypothesis Testing:}

\section{Results:}

The objective of this paper is to see the impact of personality traits and JDI on job satisfaction. The hypotheses developed in literature review are tested by using ordinary least square regression carried at $95 \%$ confidence interval. The 1.3 summarizes the results of the regression analysis;

Table 1.3: Regression Analysis Results:

\section{Dependent: JS}

\begin{tabular}{llcl} 
Independents & & & \\
\hline & $\boldsymbol{\beta}$ (Beta) & $\boldsymbol{T}$ & Significance \\
\hline Personality & .475 & 6.678 & .000 \\
\hline JDI & .449 & 6.319 & .000 \\
\hline
\end{tabular}

It is evident from the table that personality has t-value of 6.678 and p-value of .000 . This indicates that personality has significant impact on job satisfaction. Higher and significant t-values and p-values indicate that we will accept H1. Thus an individual's personality traits can explain whether he/she will be satisfied in his/her job or not.

Equally important is JDI. The table indicates that JDI has t-value of 6.319 and p-value of .000. This indicates that JDI has significant impact on job satisfaction. Higher and significant t-values and p-values indicate that we will accept H2. Thus JDI can explain variance in job satisfaction. The worker will be satisfied if attributes of JDI are taken care of by the organization. 


\section{Comparative Analysis:}

In order to determine which construct adds more to understanding job satisfaction, we will conduct $\mathrm{R}^{2}$ analysis. Firstly a regression is carried out by taking personality as explanatory variable and its $\mathrm{R}^{2}$ will be examined. Then we will conduct regression analysis by taking JDI along with personality as explanatory variables. The change in $\mathrm{R}^{2}$ will determine whether personality or JDI can explain variation in job satisfaction. The results are summarized in table 1.4;

\begin{tabular}{|c|c|c|c|c|c|}
\hline \multicolumn{6}{|c|}{ Table 1.4: Comparative Analysis } \\
\hline Independents & & & Dependent: & & \\
\hline & $\beta$ (Beta) & $\mathbf{T}$ & Significance & $\mathbf{R}^{2}$ & $\Delta$ in $\mathbf{R}^{2}$ \\
\hline Personality & .475 & 6.678 & .000 & .364 & \\
\hline JDI & .449 & 6.319 & .000 & .549 & .186 \\
\hline
\end{tabular}

The results indicate that personality $\mathrm{R}^{2}$ change is .36 while that of JDI is, 186 . This indicates that personality can explain $36 \%$ of variation in job satisfaction while JDI can explain $18.6 \%$ variation in job satisfaction. Thus in Pakistan, Personality attributes of the individual are key as to whether he/she will be satisfied from his/her job or not.

\section{Discussion:}

The paper studied the impact of personality and JDI on job satisfaction of the individuals. The results clearly indicate that both constructs has the ability to explain variation in job satisfaction.

The significance of personality traits indicate that human resource practitioners should evaluate a potential candidate psychologically before he is entrusted to do a job. If that person's personality is suitable for that job, there is a great probability that he will do that work efficiently and effectively. Further, the problem of higher turn over can be greatly reduced if recruitment is done based on personality evaluation.

JDI also cannot be ignored. The significance of JDI indicates that work, pay, promotion policies, supervisory systems and relations with co-workers have great influence on job satisfaction of the individual. As satisfied workers are more likely to stay with the organization, a human resource manager should work to enhance the attributes of JDI. Ensuring justice in promotions and rewards coupled with nice relationship with co workers can enhance the satisfaction that a person gets from his job.

\section{Conclusion and Future Research:}

The study concludes that both personality traits and JDI are ingredients of job satisfaction. These have implication for human resource manger in performing his/her tradition Human resource functions. We believe that personality traits must be considered in recruitment and selection procedures. Getting right person for the right job can be ensured by taking in to account the person's personality. Further for retention we propose that JDI can give help to human resource manager in retaining work force. By making job challenging and exciting, ensuring justice in pay and promotion and by establishing mentoring programmes, we believe that an employee will be retained in organization.

This research was conducted in limited setting, however it can be extended by incorporating other countries and different types of job settings to further investigate the constructs of JDI and personality traits. Also the adjusted $\mathrm{R}^{2}$ of our base line regression model is $54.9 \%$ that indicates that other variables such as organization citizenship behavior, ethical work practices and organization justice can be taken to explain the variation in job satisfaction.

\section{References}

[1]. AAmabile, T. M. (1993). Motivational synergy: Toward new conceptualizations of intrinsic and extrinsic motivation in the workplace. Human Resource Management Review, 3(3), 185-201.

[2]. Barrick, M. R., \& Mount, M. K. (1991). The big five personality dimensions and job performance: a meta-analysis. Personnil psychology, 44(1), 1-26.

[3]. Bonoo, J. E., \& Judge, T. A. (2004). Personality and transformational and transactional leadership: a meta-analysis. Journal of applied psychology, 89(5), 901.

[4]. Brouce, W. M., \& Blackburn, J. W. (1992). Balancing job satisfaction \& performance: A guide for human resource professionals (pp. 6-22). Westport, CT: Quorum Books

[5]. Cob-Clark, D. A., \& Schurir, S. (2012). The stability of big-five personality traits. Economics Letters, 115(1), 11-15.

[6]. Crany, C. J., Smith, P. C., \& Stone, E. (1992). Job satisfaction: How people feel about their jobs.

[7]. Dienir, E. D., Emmons, R. A., Larsen, R. J., \& Griffin, S. (1985). The satisfaction with life scale. Journal of personality assessment, 49(1), 71-75.

[8]. Digmman, J. M. (1990). Personality structure: Emergence of the five-factor model. Annual review of psychology, 41(1), 417-440.

[9]. Digman, J. M., \& Takimoto-Chock, N. K. (1981). Factors in the natural language of personality: Re-analysis, comparison, and interpretation of six major studies. Multivariate Behavioral Research, 16(2), 149-170. 
[10]. Furnham, A., Eracleous, A., \& Chamorro-Primuzic, T. (2009). Personality, motivation and job satisfaction: Hertzberg meets the Big Five. Journal of Managerial Psychology, 24(8), 765-779.

[11]. Fornham, A., Petrides, K. V., Jackson, C. J., \& Cotter, T. (2002). Do personality factors predict job satisfaction?. Personality and individual differences, 33(8), 1325-1342.

[12]. Goldberg, L. R. (1990). An alternative" description of personality": the big-five factor structure. Journal of personality and social psychology, 59(6), 1216.

[13]. Goldberg, L. R. (1993). The structure of phenotypic personality traits. American psychologist, 48(1), 26.

[14]. Golembeewski, R. T., \& Yeager, S. (1978). Testing the applicability of the JDI to various demographic groupings. Academy of Management Journal, 21(3), 514-519.

[15]. Guilford, J. P. (1975). Factors and factors of personality. Psychological Bulletin, 82(5), 802.

[16]. Hackman, J. R., \& Oldham, G. R. (1976). Motivation through the design of work: Test of a theory. Organizational behavior and human performance, 16(2), 250-279.

[17]. House, R. J., Shane, S. A., \& Herold, D. M. (1996). Rumors of the death of dispositional research are vastly exaggerated. Academy of Management Review, 21(1), 203-224.

[18]. Hundleby, J. D., Pawlik, K., \& Cattell, R. B. (1965). Personality factors in objective test devices: A critical integration of a quarter of a century's research. RR Knapp.

[19]. Maslow, A. H., Frager, R., \& Fadiman, J. (1970). Motivation and personality (Vol. 2). New York: Harper \& Row

[20]. Mayo, E. (1930). The Hawthorne Experiments. You will recall that in unit, 12

[21]. McAdams, D. P. (1992). The five-factor model in personality: A critical appraisal. Journal of personality, 60(2), 329-361.

[22]. McCrae, R. R., Costa, P. T., de Lima, M. P., Simões, A., Ostendorf, F., Angleitner, A., ... \& Piedmont, R. L. (1999). Age differences in personality across the adult life span: parallels in five cultures. Developmental psychology, $35(2), 466$.

[23]. McCrae, R. R., \& Costa Jr, P. T. (1997). Personality trait structure as a human universal. American psychologist, $52(5), 509$.

[24]. Nagami, M., Tsutsumi, A., Tsuchiya, M., \& Morimoto, K. (2010). Job control and coworker support improve employee job performance. Industrial health, (0), 1006240012.

[25]. Olver, J. M., \& Mooradian, T. A. (2003). Personality traits and personal values: a conceptual and empirical integration. Personality and individual differences, 35(1), 109-125.

[26]. Organ, D. W., \& Lingl, A. (1995). Personality, satisfaction, and organizational citizenship behavior. The Journal of Social Psychology, 135(3), 339-350.

[27]. Raja, U., Johnns, G., \& Ntalianis, F. (2004). The impact of personality on psychological contracts. Academy of Management Journal, 47(3), 350-367.

[28]. Smith, K., \& Kendall, L. Hulin (1969). The measurement of satisfaction work and retirement.

[29]. Smith, P. C. (1969). The measurement of satisfaction in work and retirement: A strategy for the study of attitudes.

[30]. Taormina, R. J. (1999). Predicting employee commitment and satisfaction: The relative effects of socialization and demographics. International Journal of Human Resource Management, 10(6), 1060-1076.

[31]. Tailor, F. W. (2013). Scientific management. Routlidge.

[32]. Tailor, F. W. (1911). The principles of scientific management. New York, 202.

[33]. Watsen, D., \& Clark, L. A. (1997). Extraversion and its positive emotional core.

[34]. Worrall, T. G. (2004). School psychologists' job satisfaction: ten years later (Doctoral dissertation, Virginia Polytechnic Institute and State University). 